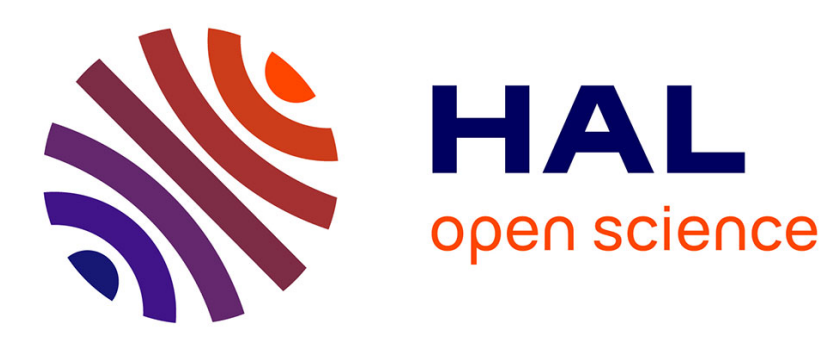

\title{
PHASE TRANSITIONS AND SPALL FRACTURES OF ZIRCONIUM UNDER EXPLOSIVE LOADING
}

E. Kozlov

\section{To cite this version:}

E. Kozlov. PHASE TRANSITIONS AND SPALL FRACTURES OF ZIRCONIUM UNDER EXPLOSIVE LOADING. Journal de Physique IV Proceedings, 1991, 01 (C3), pp.C3-675-C3-679. 10.1051/jp4:1991394 . jpa-00250540

HAL Id: jpa-00250540 https://hal.science/jpa-00250540

Submitted on 1 Jan 1991

HAL is a multi-disciplinary open access archive for the deposit and dissemination of scientific research documents, whether they are published or not. The documents may come from teaching and research institutions in France or abroad, or from public or private research centers.
L'archive ouverte pluridisciplinaire HAL, est destinée au dépôt et à la diffusion de documents scientifiques de niveau recherche, publiés ou non, émanant des établissements d'enseignement et de recherche français ou étrangers, des laboratoires publics ou privés. 


\title{
PHASE TRANSITIONS AND SPALL FRACTURES OF ZIRCONIUM UNDER EXPLOSIVE LOADING
}

\author{
E.A. KOZLOV
}

All-Union Research Institute of Technical Physics, P.O. Box 245, 454070, Chelyabinsk-70, USSR

\begin{abstract}
Résumé : Les résultats de recherche sur l'évolution adiabatique du choc et la strusture de l'onde de choc dans le zirconium sont présentés dans un domaine où les transitions polymorphiques primitives et secondaires existent. Les caractéristiques sur l'adiabatie du choc à $\sigma_{\mathrm{x}}=9,2 \mathrm{GPa}, \mathrm{V} / \mathrm{V}_{\mathrm{O}}=0,9184$ découverts par les analyses métallographiques et radiographie $X$ sur.les échantillons sont liées à la transition de phase irréversible $\alpha->\omega$ dans le zirconium. Les paramètres de relaxation rapide du précurseur élastique dans la phase $\alpha$ sont estimés ainsi que ceux des conditions d'écaillage. On note des microfissures à caractère visqueux dans la phase $\alpha$ et d'autres à caractère fragile dans la phase $\omega$.
\end{abstract}

Abstract - Results of invest igat ing the shock adiabat and the shock wave structure in zirconium, in the region of the first and the second polymorphic transitions, are presented. The discovered feature on the shock adiabat at $\sigma_{x}=9.2 \mathrm{GPa}, Y / N_{0}=0.9184$, as the results of metal lographic and roentgenostructural invest igat ions of conserved samples showed, was connected with proceeding the irreversible $\alpha+\omega$ phase transition in zirconium. Parameters of quickly relaxing elastic precursor in the initial a-phase were estimated. Conditions of spall fracture arising were determined. It was noted a viscous character of spall microfractures in $a$-phase and a brittle one in $\omega$-phase.

\section{1.- Introduction.}

Zirconium is one of a faw elements, for which it was succeeded to conserve the high pressure phase in the metastable state after static /1/ and shock-wave pressure /2/ effects and the subsequent unloading. If under the static loading it was investigated the zirconium phase diagram in every detail (f igure 1) in the range of up to $10 \mathrm{GPa}$ (in the range of atw transition), the data of zirconium behavior under the explosive loading /2-4/ were restricted. In $/ 3,4 /$, while using the discrete method of the wave process registration, it was obtained 25 points of shock adiabat of zirconium in pressure range of $15-150$ GPa.

The aims of this work were:

- obtaining data of shock compression and shock-wave structure in the region of the discovered /3/ phase transition, as well as in the range below $15 \mathrm{GPa}$, that was not earl ier invest igated exper imentally;

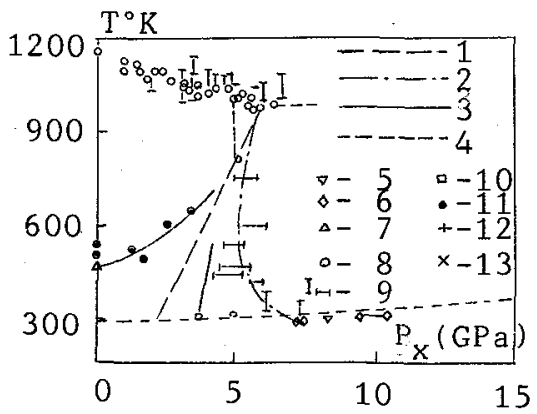

Fig.1. - Phase diagram of unalloyed zirconium. 1 - boundary of equil ibrium $a * \omega$ phase transition /17/; 2 - boundary of $\alpha+\omega$ transition according to /14/; 3 - boundary of $\omega \rightarrow \alpha$ transition according to /15/; 4 - shock adiabat. Exper imental points: 5 - $/ 11 /$, $6-/ 12 /, 7-/ 14 /, 8-/ 13 /, 9-/ 14 /, 10-/ 2 /, 11-/ 15 /, 12-/ 17 /, 13-/ 18 /$. 
- investigating the spall fracture of unalloyed zirconium in $\alpha$ - and $\omega$-phases;

- study ing structure changes and the phase composition of samples, subjected to the explosive loading and conserved after tests;

- analysis of changing mechanical characteristics (microhardness) of material, underwent the elasto-plast ic deformation in the region of initial $\alpha$ - phase and subjected to irreversible $\alpha+\omega$ phase transition.

2.- Material, samples and explosive loading conditions.

Invest igations were conducted on unal loyed zirconium, produced by vacuum remelt ing of iodide zirconium bars. zirconium content was 99.8 mass 8. The main impurities were nickel $\left(6.6 .10^{-2}\right.$ mass 8 ) and silicon $\left(410^{-3}\right.$ mass 8 ). Roentgenostructural phase and metallographic analyses show the availability of only a-phase of zirconium in the initial state. The initial density and nicrohardness are equal to be $6.50 \mathrm{~g} / \mathrm{cm}^{3}$ and $125 \mathrm{~kg} / \mathrm{mg}^{2}$, respect ively.

Samples of two types were used (f igure 2):

- wedges, which were out from the parallelepiped, having sizes $30 \times 90 \times 135$ mm with $20^{\circ} 00^{\prime}$ and $25^{\circ} 00^{\prime} \pm 5^{\prime}$ angles;

- hooves, mill ing from disks, having sizes $120 \times 30$ min with $9^{\circ} 00^{\prime} \pm 5^{\prime}$ angle.

The explosive loading of the first type samples was real ized by stiding detonation and the second type samples - by normat datonation of explosives, having different powers and thicknesses, as shown in figure 2.

Loading conditions were selected so, that:

- to real ize states in the region of the first and the second phase transitions while using zirconiul samples;

- to conserve samples, which uderwent explosive loading in the region of the first $a+\omega$ transition for the following studying them by metallographic and roentgenostructurat analysis methods and by measur ing icrohardness;

- to real ize on the conserved samples spall fractures of different extent in the range of $\alpha$ - and $\omega$-phase of zirconium for the later compar ing the character of spall micro- and macrofractures with the registered parameters of loading pulse.

\section{3.- Exper imental method.}

For the wave process recording imnediately under explosive loading it was used the known /5-8/ wethod of the optical lever, which allous:

- to perform registrating not one, but two shock compression parameters simultaneously: the wave velocity and the free surface velocit ies of samples;

- to real ize cont inuous registrating the free-surface velocity during the sequential output of compression and rarefaction waves upon it;

- to obta in information in one experiment at once for several free surface points, removed from loading surfaces in different distances.

Some typical photo-chronograms are shown in figure 2.

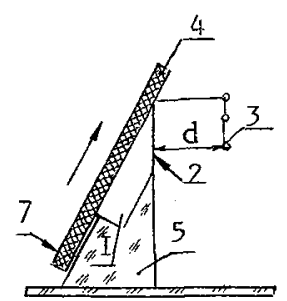

a)

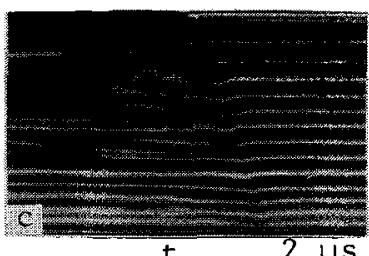

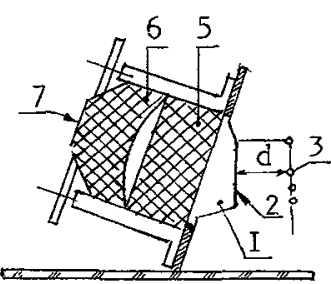

b)

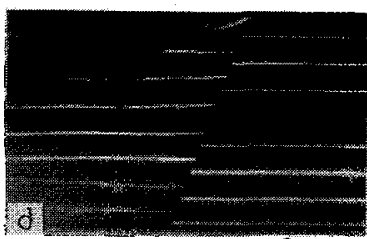

$\mathrm{t} \quad 2 \mu \mathrm{s}$

Fig. 2.- Exper imental conduct ing scheses $(a, b)$ and typical photo-chronograms $(c, d)$. $c$ - plastic explosive with 1 棝 thickness; $d$ - TNT-RDX $3 / 7$ with 40 thikness; 1 - studied sample; 2 - pol ished free surface of sample; 3 - sl it diaphrag systen; 4 - plate explosive with thickness of $0.35-20$ mm; 5 - explosive charge $0120 \times 20-120 \mathrm{~mm} ; 6$ - explosive lens; 7 - detonator. 

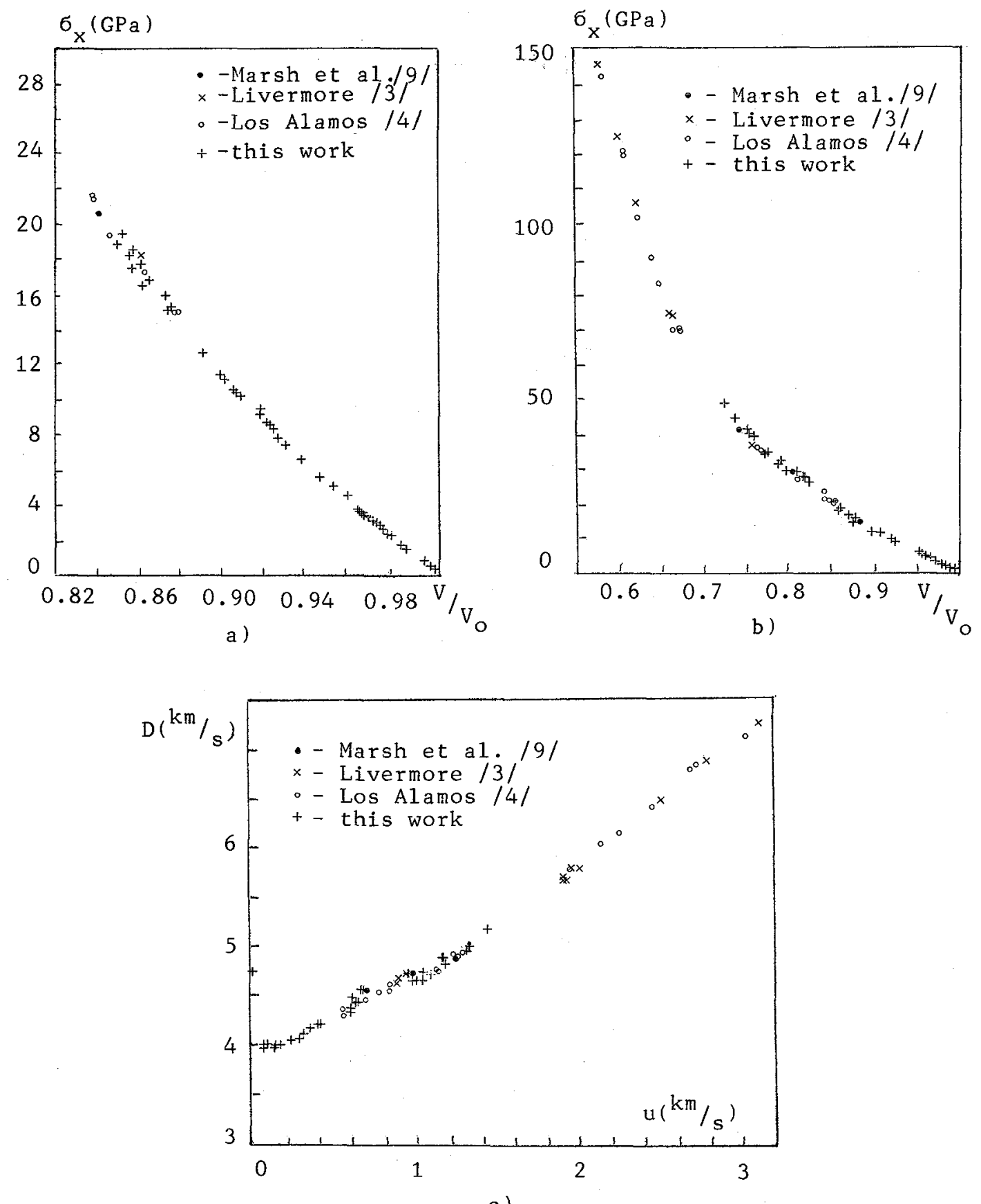

Fig. 3. - Shock adiabat of unalloyed zirconium, a) $-\left(\sigma_{x}, V / \mathrm{V}_{0}\right)$ is in the region up to $28 \mathrm{GPa}$; b) $-\left(\sigma_{x}, V / V_{0}\right)$ is in the region up to $\left.150 \mathrm{GPa} ; c\right)-(D, U)$-relationship. It's seen the parameters of elastic precursor in initial $\alpha$-phase, the feature, corresponding to the $\alpha+\omega$ phase transition at $\sigma_{x}=9.2 \mathrm{GPa}$, and plateau, corresponoing to the $\omega+x$ phase transition at $\sigma_{x}=26-36.5 \mathrm{GPa}$. 
4.- Results.

By using the optical lever method there were obtained 65 points on the shock adiabat of unalloyed zirconium in the range of $0.1-50.0 \mathrm{GPa}$ (f jigure 3).

There were verified the results $/ 3,4 /$ of zirconium shock compression, including results, obtained in the phase transition region under the stress of $26.0-36.5 \mathrm{GPa}$. It was found that one-wave configuration was spreading along zirconium in the mentioned stress range (figure $2 \mathrm{~d}$ ),

Data of shock coupression and of shock-wave structure, in uninvestigated earlier stress range up to 15 GPa (f igure $3 a$ ), were obtained. It was discovered a slight bend in the zirconium shock ad iabat at $\sigma_{x}=9.2 \mathrm{GPa}_{3} \mathrm{~V} / \mathrm{V}_{0}=0.9184,0=4.135, u=0.340$

$\mathrm{km} / \mathrm{s}$, which was, probably, connected with proceeding a $a+\infty$ transition in zirconiun under the explosive loading. The fact of proceeding the irreversible $a+\omega$ transition was conf irmed by wetallographic and roentgenostructural invest igation results of the saue samples (figure $4 a, b$ ).
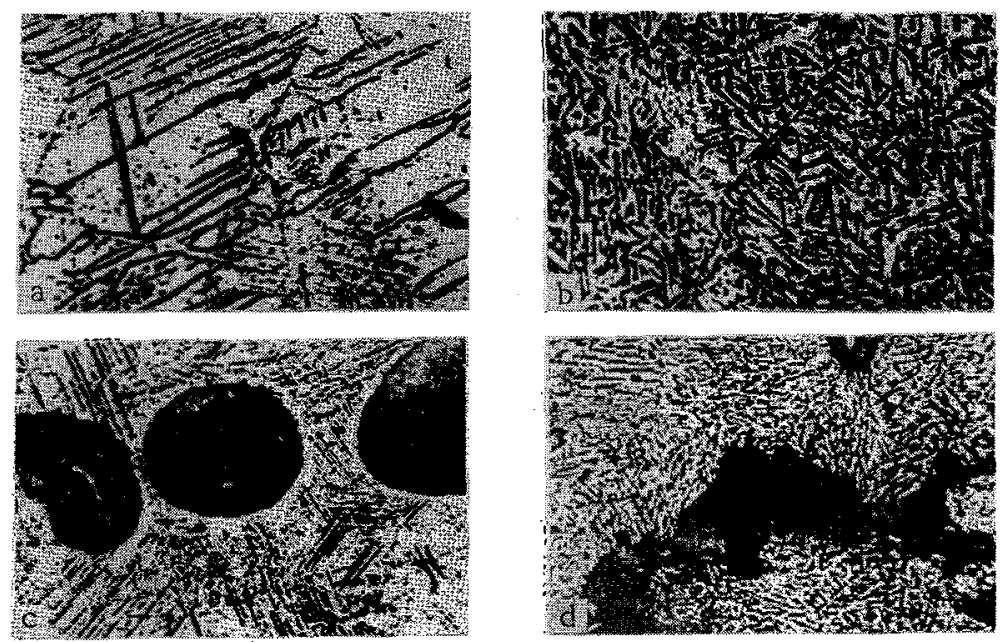

Fig. 4.- Microstructures of the initial a-phase of zirconium $(a-x 200)$ and w-phase of zirconium (b-x1000), that conserved after explosive loading in wetastable state. Incipient spall fracture in a-phase $(c-\times 200)$ and brittle wicrocraks in w-phase $(d-x 200)$.

In zirconiub it was observed arising two-wave configurations (figure $2 \mathrm{c}$ ), connected with elasto-plastic deformation of $z$ irconium in the region of the initial a-phase. Parameters of the quickly relaxing elastic precursor were est inated to be equal to: $\sigma_{x}^{\mathrm{HEL}}=0.66-0.12 \mathrm{GPa}, U=0.022 \sim 0.004 \mathrm{~km} / \mathrm{s}$.

There were received spall fracture data of unalloyed zirconiun in $\alpha$ - phase in case of loading it by sliding detonation of the plate of plastic explosive (figures $4 c, d$ and figure 5 ).

As at $/ 6 /$, the spall macrofracture, arising in zirconium, was observed while outconing on to the sample free surface, the plastic wave, the amplitude of which is equal to $3.0-4.0 \mathrm{GPa}$, under the conditions of pressure orop in the wave front: $\frac{d \phi}{d r}=0.13-0.32 \mathrm{GPa} / \mathrm{mm}$, where $r=x / \cos \theta$ is the distance, noved by the shock-wave front, $x$ is variable thickness of the wedge sample and $\theta$ is the angle, formed by the shock-wave front and initial position of the loading surface.

By the metallographic analyses there was obtained information of zirconium spall icrofracture character in $a$ - and $\omega$-phase at the level of separate material grains (f jgure $4 c$, d).

By roentgenographic methods there were determined parameters of a grid of w-phase, renained in the metastable state after unloading: $a=5.035 \&$ and $c=3.110 \&$. These vatues are in agreement with data $/ 2 /$, however, appearing the w-phase in conserved samples was observed in our experiments at higher pressures.

It was found the essential (by a factor of two) wicrohardness increase of the material, subjected to explosive loading. This increasing was connected mainly with proceeding the irreversible atw transition in zirconium. Only insignificant changing the aicroharóness of zirconiun, subjected to elasto-plastic deformation in the region of the initial a-phase, was observed. 


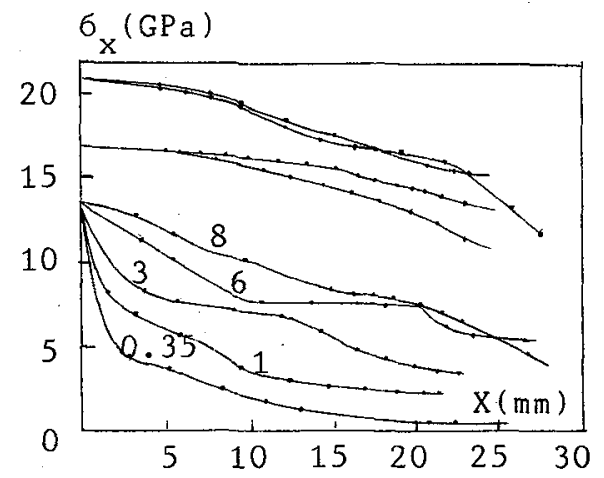

Fig. 5.- Change of stresses along the thickness of wedge samples while their loading by sliding detonation of plate charge explosives, haying different powers and thicknesses. Numbers near the curves correspond to the thicknesses of used plastic explosive layer.

\section{5.- Conclusion.}

Results of investigating the shock adiabat and the shock wave structure in zirconium, in the region of the first and the second polyworphic transitions, are presented. The discovered feature on the shock ad iabat at $\sigma_{x}=9.26 \mathrm{~Pa}, V / \mathrm{V}_{0}=0.9184$, as

the results of metallographic and roentgenostructurat investigations of conserved samples showed, was connected with proceeding the irreversible $a+\omega$ phase transition in zirconium. Parameters of quickly relaxing elastic precursor in the in itial $\alpha$-phase were estimated. Conditions of spall fracture arising were determined. It was noted a viscous character of spall microfractures in a-phase and a brittle one in $\omega$-phase.

\section{REFERENCES}

1. Tonkov E.Y., Phase Diagrams of Elements under High Pressures (Nauka Moscow 1979)

2. Kutsar A.R., German Y.N., Nosova G.J., Rep. Acad. Sci. USSR 213 (1973) 81

3. H. van Thiel, Kusubov A.S., Mitchell A.C., Compendiun of Shock Have Data, LIN, UCRL 50108, 1967.

4. Marsh S.P., Los-Alamos Shock Hugoniot Data, University of Cal ifornia Press, Berkely, Los Angeles, Londion, 1980.

5. Fowles 6.R., J. Appl. Phys. 38 (1961) 1475

6. Kozlov E.A., Nuzirya A.K., Chinkova R.H., et al., Phys, of Comb. \& Expl. 4 (1984) 123

7. Kozlov E.A., Rep. Theses of the First All-Union Symposium on Macroscopic Kinetics and Chemical Gas Dynamics, 1984, v. 2, part 2, 52-53.

8. Gornovoy A.A., Kozlov E.A., Shorochov E.V. et al., Phys. of Comb. \& Expl. 1 (1989) 142

9. Marsh J.M., Rice H.H., McQueen G. at al., Phys. Rev. 108 (1957) 196

10. Jamieson J.C., Science 140 (1963) 72

11. Bridgman P.W., Proc. Amer. Acad. Árts. Sci. 81 (1952) 165

12. Vereschagin L.F., Semerchan A.A., Kus in N.I. et al., Rep. Acad. Sci. USSR 138 (1961) 84

13. Jayaramen A., Klement W., Kennedy G.C., Phys. Rev. 13 (1963) 644

14. It inosae, Proc. of the Second Symposiuin on High Pressures, 24-26 Dec. 1969, Sendai, Japan.

15. Silbershta in V.A., Nosova G.I., Estr in E.I., Phys. of Met. \& Met. Sci. 35 (1973) 584

16. Bychkov Y.F., Lihanin Y.N., Maltzev V.A., Phys, of Met, Met. Sci. 36 (1973) 413

17. Silbershtain V.A., Chistotina N.P., Zharov A.A., et al., Phys. of Het. \& Met. Sci. 39 (1975) 445

18. Yohra Y.K., J. Nucl, Mat, 75 (1978) 288 